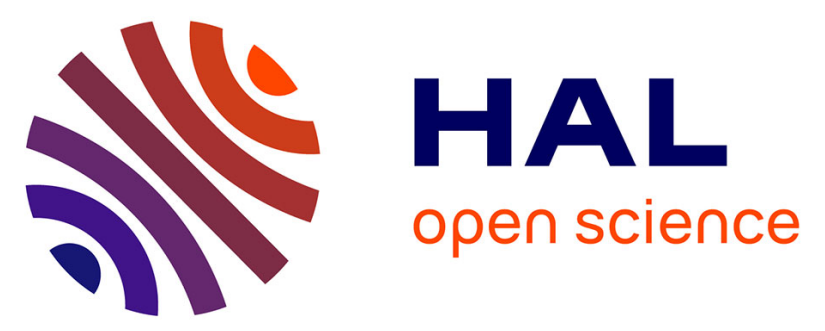

\title{
Coupling Electrochemical Adsorption and Long-range Electron Transfer: Label-free DNA Mismatch Detection with Ultramicroelectrode (UME)
}

Nivedita Basu, Thu Huong Ho, François-Xavier Guillon, Yuanyuan Zhang, Pascal Bigey, Bhat Navakanta, Fethi Bedioui, Mathieu Lazerges

\section{To cite this version:}

Nivedita Basu, Thu Huong Ho, François-Xavier Guillon, Yuanyuan Zhang, Pascal Bigey, et al.. Coupling Electrochemical Adsorption and Long-range Electron Transfer: Label-free DNA Mismatch Detection with Ultramicroelectrode (UME). Electroanalysis, 2019, 31 (11), pp.2232-2237. 10.1002/elan.201900357 . hal-02189989

\section{HAL Id: hal-02189989 \\ https://hal.science/hal-02189989}

Submitted on 20 Jul 2019

HAL is a multi-disciplinary open access archive for the deposit and dissemination of scientific research documents, whether they are published or not. The documents may come from teaching and research institutions in France or abroad, or from public or private research centers.
L'archive ouverte pluridisciplinaire HAL, est destinée au dépôt et à la diffusion de documents scientifiques de niveau recherche, publiés ou non, émanant des établissements d'enseignement et de recherche français ou étrangers, des laboratoires publics ou privés. 


\title{
Coupling Electrochemical Adsorption and Long-range Electron Transfer: Label-free DNA Mismatch Detection with Ultramicroelectrode (UME)
}

\author{
Nivedita Basu, ${ }^{[a, d]}$ Thu Huong Ho, ${ }^{[a]}$ François-Xavier Guillon, ${ }^{[a]}$ Yuanyuan Zhang,${ }^{[a]}$ Pascal Bigey, ${ }^{[b, c]}$ \\ Bhat Navakanta, ${ }^{[\mathrm{d}]}$ Fethi Bedioui, ${ }^{*[\mathrm{a}]}$ and Mathieu Lazerges ${ }^{[\mathrm{a}, \mathrm{b}, \mathrm{c}]}$
}

\begin{abstract}
A new electrochemical hybridization transduction pathway, obtained by coupling electrochemical adsorption and long-range electron transfer through double-stranded DNA, was investigated using ultramicroelectrode (UME). The results show that long-range electron transfer does not occurs exclusively throws wellpacked and organized self-assembled DNA monolayers.
\end{abstract}

This approach is used to investigate long-range electron transfer properties of both single- and double- stranded short synthetic DNA and DNA plasmids. Single mismatch electrochemical detection protocol of non-labelled short synthetic DNA, without heating or probe labelling, in a 10 minutes protocol, was in fine performed.

Keywords: DANA - Electrochemical Adsorption · Long-Range Electron Transfer · Mismatch · Ultramicroelectrode

- Dear Author, according to the Author's Guidelines (Wiley) the References have to be structured different. Please correct all citations exactly as follows (in the WORD-File, please. Thank you):

Example for Journals: a) A. Au.., B. R. Coauthor, $Z$. Anorg. Allg. Chem. 2006, 632, 1-5; b) A. Author, B. Coauthor, Angew. Chem. 2006, 118, 1-5; Angew. Chem. Int. Ed. 2006, 45, 1-5.

Example for Books: J. W. Grate, G. C. Frye in Sensors Update, 1st ed., Vol. 2 (Eds.: H. Baltes, W. Göpel, J. Hesse), Wiley-VCH, Weinheim, 1996, pp. 10-20.

Example for Theses, Dissertations: W. Schulz, Dissertation, Univ. Rostock, 1965.

Important: Please take attention to italics and boldface $\mathbf{E}$

\section{Introduction}

Electrochemical adsorption of nucleic acids onto carbon paste electrode was firstly used to quantify RNA [1], single-stranded DNA [2] and DNA plasmids $[3,4]$ samples. The electrochemical adsorption of DNA was performed at $+0.5 \mathrm{~V}$ vs $\mathrm{Ag} / \mathrm{AgCl}$ potential during $2 \mathrm{~min}$. The adsorbed nucleic acids were then detected using the irreversible guanine oxidation peak at $+1.0 \mathrm{~V}$ vs Ag/ $\mathrm{AgCl}$. The driving force of electrochemical adsorption is the electrostatic interaction between the negative charges of DNA phosphate backbone and the positive charges of the graphite surface due to electrode polarization. This technique, combining electrochemical adsorption of nu- cleic acids and subsequent irreversible electrochemical oxidation of their guanine base, was used to perform electrochemical hybridization transduction of various nucleic acids targets: 20-base poly(C) DNA [5] and 21base and 27-base DNA [6]. Moreover, single mismatch detection of a 17-base DNA was performed at $42^{\circ} \mathrm{C}$ temperature [7]. In the last two decades, several biosensors based on this architecture were developed, yielding to detection limits in the femtomolar range $[8,9]$. The principal advantages of this approach are the use of non-labeled nucleic acid probes and the rapid probe adsorption. Its main limitation is the irreversible DNA oxidation process that does not allow further use of the biosensor.

Elsewhere, the distance dependence of electron transfer in DNA duplex was unambiguously established

[a] N. Basu, T. H. Ho, F.-X. Guillon, Y. Zhang, F. Bedioui, M. Lazerges

Chimie ParisTech, PSL University, CNRS, Institute of Chemistry for Life and Health Sciences (i-CLeHS), Paris, France

E-mail: $\mathbf{\square}$ email missing $\mathbf{\square}$

[b] P. Bigey, M. Lazerges

UTCBS, U 1263 INSERM, Université Paris Descartes, Université Sorbonne Paris Cité, Paris 75006, France

[c] P. Bigey, M. Lazerges

UTCBS, UMR 8258 CNRS, Université Paris Descartes, Université Sorbonne Paris Cité, Paris 75006, France

[d] N. Basu, B. Navakanta

Centre for Nano Science and Engineering (CeNSE), Department of Electrical Communication Engineering, Indian Institute of Science, Bangalore 560012, India

Supporting information for this article is available on the WWW under https://doi.org/10.1002/elan.201900357 
20 years ago by measurements of steady-state fluorescence quenching between a fluorescent electron donor and an electron acceptor covalently grafted at different length of a DNA duplex [10]. Quenching of the fluorescent probe occurs when the spacing length between electron donor and acceptor is inferior to $30 \AA$, which is the long-range electron transfer distance limit. The authors rose from this study that a single mismatch induces a large decrease of long-range electron transfer efficiency due to disrupting of $\pi$-stacking of DNA base along the duplex helix axis. This property was used few years later to design electrochemical DNA biosensors based on long-range electron transfer through DNA selfassembled monolayers (SAM) of thiol-labeled probes adsorbed onto gold surface via $\mathrm{S}-\mathrm{Au}$ bond. The electrochemical transduction of hybridization was performed by reduction of $\left[\mathrm{Fe}(\mathrm{III})(\mathrm{CN})_{6}\right]^{3-}$ to $\left[\mathrm{Fe}(\mathrm{II})(\mathrm{CN})_{6}\right]^{4-}$ at $-0.35 \mathrm{~V}$ vs saturated calomel electrode catalyzed by methylene blue (MB), which is a redox and conjugated plane molecule intercalated in the DNA duplex [11]. Diffusion of $\left[\mathrm{Fe}(\mathrm{III})(\mathrm{CN})_{6}\right]^{3-}$ within the DNA monolayer is prevented by electrostatic repulsion with the phosphate residues of the DNA backbone. A recent study demonstrates that DNA-mediated electron transfer efficiency is increased for reduction and depends on the structure of the DNA duplex sequence: the electron transfer rate for a AT oligonucleotide duplex is about 5 times the rate of a CG one [12]. The major advantage of this electrochemical transduction pathway is the detection of a single mismatch without heating [13]. Its main limitations are the chemical labeling of the probe with a sulfured ligand and the slow adsorption process of the probe onto the gold surface. Many biosensors based on this architecture were developed the last two decades, yielding to a LOD in the femtomolar range $[14,15,16]$.

The aim of this study is to investigate the coupling of DNA electrochemical adsorption, which is rapid and do not require chemical labelling, to long-range electron transfer of double-stranded DNA, which is selective, in order to combine advantages of the two techniques for DNA assay purposes.

\section{Experimental Section}

Electrochemistry. A two-electrode setup (Scheme 1) consisting of a working UME (graphite $\varnothing 33 \mu \mathrm{m}$ or platinum $\varnothing 25 \mu \mathrm{m})$ and a counter millielectrode of the same metal (graphite or platinum $\varnothing 2 \mathrm{~mm}$ ) was used in order to avoid the use of a reference electrode. As previously reported, such two-electrode setup is interesting for the development of miniaturized analytical devices as it requires less complex equipments than a three-electrode setup. Elsewhere, the redox $\mathrm{Fe}(\mathrm{II}) / \mathrm{Fe}$ (III) wave is centered at the axes origin. Indeed, as the two electrodes are made from the same metal (geld), the equilibrium potential is equal to $0 \mathrm{~V}$, and so the application of a feeble potential difference yields to a the development of a high current suitable for analytical purposes $[13,14]$.

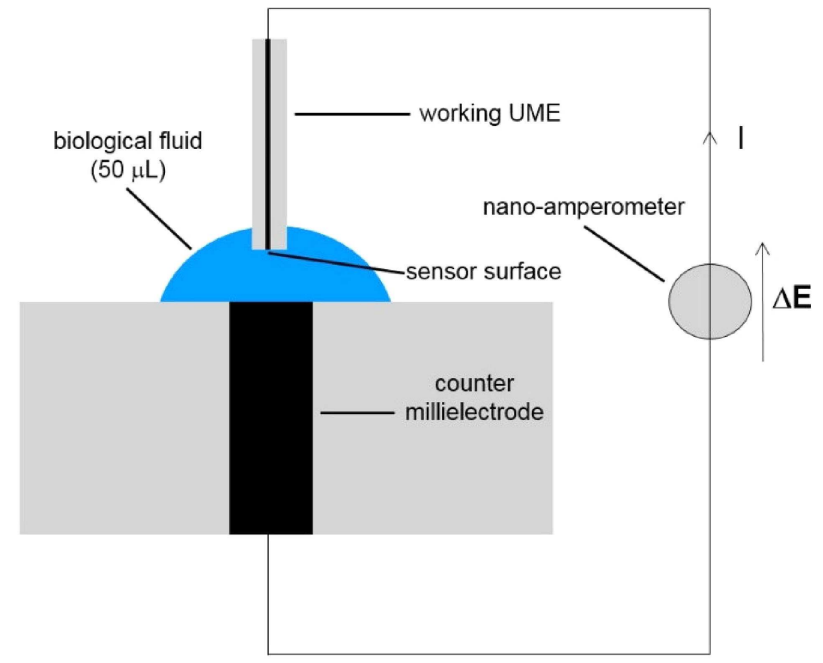

Scheme 1. Electrochemical two-electrode setup (not real scale).

The electrodes were successively polished using P800/ P2400 (9-22 $\mu \mathrm{m}$ particle size) and P1200/P4000 (6-15 $\mu \mathrm{m}$ particle size) silicon carbide disks (Pesi) during $1 \mathrm{~min}$ each. Amperometric measurements were performed with a Petit Ampère LC-3C (BAS) using the $10 \mathrm{nA}$ range and the $0.03 \mathrm{~Hz}$ low-pass RC filter that allows measurements without the use of a Faraday cage. The electrolyte volume was $50 \mu \mathrm{L}$.

Chemical products. Water was distillated and deionized prior to use $(\rho=15 \mathrm{M} \Omega . \mathrm{cm}) .99 .8 \% \mathrm{NaCl}$ (Riedel-de Haën), $\mathrm{K}_{3}\left[\mathrm{Fe}(\mathrm{CN})_{6}\right]$ denoted as $\mathrm{Fe}(\mathrm{III})$ (Rhône-Poulenc), $\mathrm{K}_{4}\left[\mathrm{Fe}(\mathrm{CN})_{6}\right], 3 \mathrm{H}_{2} \mathrm{O}$ denoted as $\mathrm{Fe}(\mathrm{II})$ (Riedel-de Haën) and methylene blue (MB) (Rhône-Poulenc) were used without further purification.

DNA strands. Synthetic 21-base oligonucleotides (Table 1) were purified using reverse phase HPLC by the provider (Eurogentec).

The probe sequence is complementary to miR215, a colon cancer biomarker [17]. The 4271 base-pair (bp) DNA is a plasmid encoding a soluble receptor of TNF- $\alpha$ [18] and the $2023 b p$ DNA is a non-coding small plasmid [19].

\section{Results and Discussion}

The detailed raw data of this study ( $I v s \Delta E$ responses of UMEs) are included in the supplementary material file.

Table 1. 21-base oligonucleotides sequences of probe (P), target (T), targets with 1 mismatch (Tm1 and Tm11) and 2 mismatches (Tm5,11).

\begin{tabular}{|c|c|}
\hline $\mathrm{P}$ & TAC TGG ATA CTT AAC TGT CGT \\
\hline $\mathrm{T}$ & ATG ACC TAT GAA TTG ACA GAC \\
\hline Tㅆ 1 & $\underline{\mathbf{T} T G}$ ACC TAT GAA TTG ACA GAC \\
\hline$\overline{\mathrm{Tm} 11}$ & 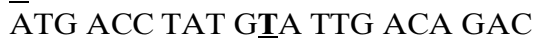 \\
\hline $\operatorname{Tm} 5,11$ & ATG AGC TAT GTA TTG ACA GAC \\
\hline
\end{tabular}




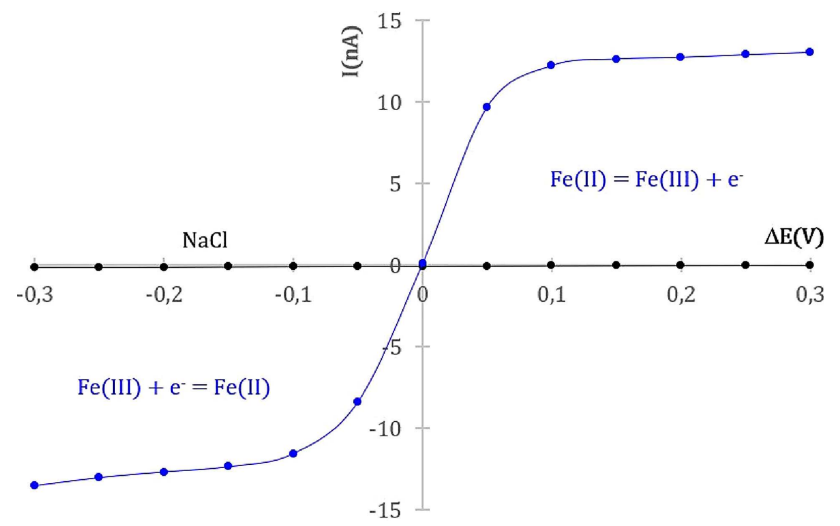

Fig. 1. Amperometric response of $25 \mu \mathrm{m}$ diameter platinum UME in $\mathrm{NaCl} 0.5 \mathrm{M}$ (black discs) and $0.5 \mathrm{M} \mathrm{NaCl}, 3.0 \mathrm{mM} \mathrm{K}_{3}[\mathrm{Fe}$ (III) $\left.(\mathrm{CN})_{6}\right]$ and $3.0 \mathrm{mM} \mathrm{K}_{4}\left[\mathrm{Fe}(\mathrm{II})(\mathrm{CN})_{6}\right], 3 \mathrm{H}_{2} \mathrm{O}$ (blue discs), the current was recorded for each potential after $1 \mathrm{~min}$. of polarization.

Two-electrode setup electrochemical responses. Electrochemical responses of a platinum UME between $-0.3 \mathrm{~V}$ and $+0.3 \mathrm{~V}$ (Figure 1) indicate that the background current related to $\mathrm{NaCl}$ electrolyte is negligible compared to that of $\mathrm{Fe}(\mathrm{III}) / \mathrm{Fe}(\mathrm{II})$ redox process. The mean value of diffusion limit current, equal to $12.5 \mathrm{nA}$ $(\Delta E= \pm 0.15 \mathrm{~V})$, is in the range of the $9.5 \mathrm{nA}$ calculated for the theoretical stationary faradaic solution of a disc electrode:

$I=4 \times z \times F \times D \times C \times R$

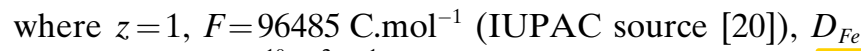
${ }_{(I I I) / F e(I I)}=6.4 \times 10^{-10} \mathrm{~m}^{2} . \mathrm{s}^{-1}$ (mean value [21]), $C_{\mathrm{Fe}(I I I) / \mathrm{Fe}(I}$ $3 \mathrm{mM}$ and $r=12.5 \mu \mathrm{m}$.

Electrochemical single-stranded DNA adso. platinum and graphite UMEs. $\mathrm{Fe}(\mathrm{II})$ oxidation current $\mathrm{I}_{0}$ was measured before electrochemical adsorption of single-stranded DNA (ss-DNA) at a $+0.05 \mathrm{~V}$ for both $\mathrm{Pt}$ and graphite UMEs (Scheme 2A): oxidation current for this potential difference is close to the maximum one (Figure 1). The electrochemical adsorption of ss-DNA was performed by applying a positive potential difference $\Delta E$ ranging from $0.1 \mathrm{~V} / 0.5 \mathrm{~V}$ (Scheme $2 \mathrm{~B}$ ). $\mathrm{Fe}$ (II) oxidation current $\mathrm{I}_{1}$ was then measured after the electrochemical adsorption step $\mathrm{B}$ again at a $+0.05 \mathrm{~V}$ (Scheme 2C). For all these experiments, the electrolyte contains DNA and $\mathrm{Fe}(\mathrm{II}) / \mathrm{Fe}$ (III) in order to perform the electrochemical adsorption and the oxidation of $\mathrm{Fe}(\mathrm{II})$ in a one-pot protocol.

The Fe(II) oxidation currents before $\left(I_{A u}\right)$ and after $\left(I_{s s}\right)$ the $s s$-DNA electrochemical adsorption were measured for different conditions: electrochemical adsorption potential ranging from $+0.1 \mathrm{~V} /+0.5 \mathrm{~V}$ and electrochemical adsorption time ranging from $3 \mathrm{~min}$. to $15 \mathrm{~min}$. The $I_{s s} / I_{A u}$ ratio of the oxidation current after and before ssDNA adsorption was then calculated (Figure 2).

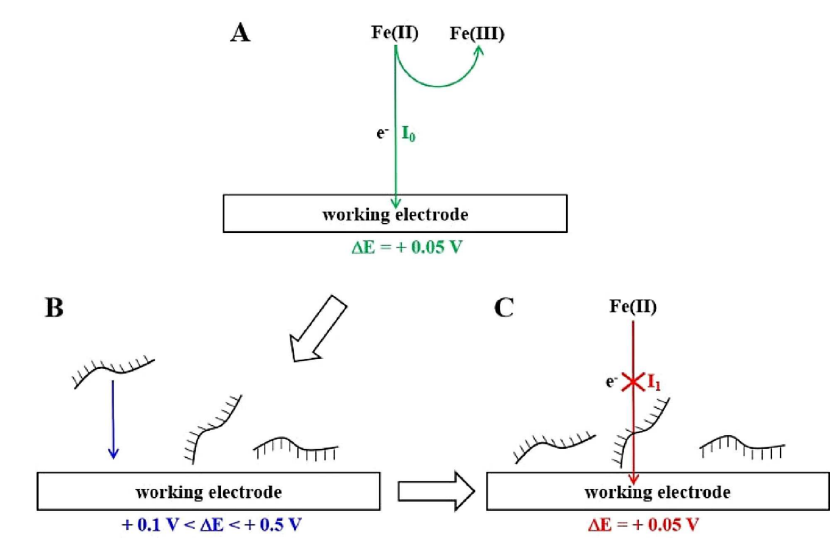

Scheme 2. (A) Fe(II) oxidation before electrochemical adsorption of $s s$-DNA. (B) Electrochemical adsorption of $s s$-DNA. (C) Fe (II) oxidation after the electrochemical adsorption of ss-DNA. Electrolyte: $3.0 \mathrm{mM} \mathrm{Fe}(\mathrm{II}) ; 3.0 \mathrm{mM} \mathrm{Fe}(\mathrm{III}) ; 0.5 \mathrm{NaCl}$ and $1.5 \times$ $10^{-6} \mathrm{M} s s$-DNA probe.
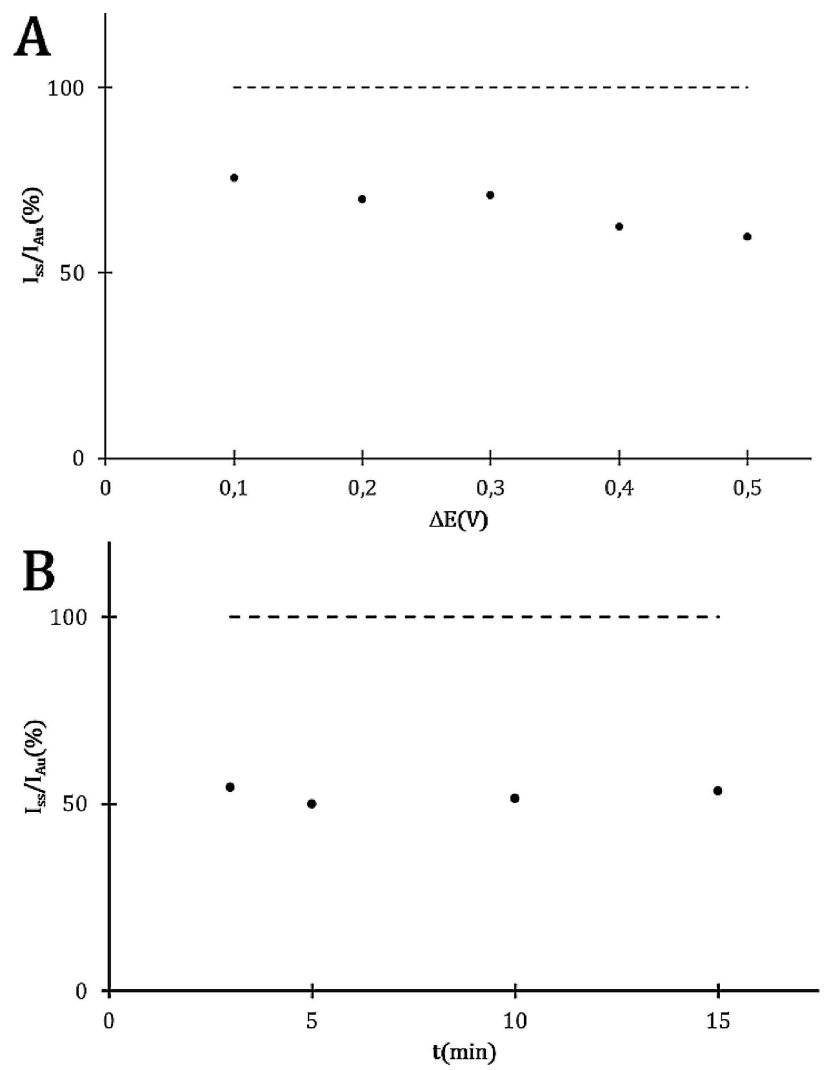

Fig. 2. Ratio $I_{s s} / I_{A u}$ of current measured at $+0.05 \mathrm{~V}$ with Pt UME before $\left(I_{A u}\right)$ and after $\left(I_{s s}\right)$ the electrochemical adsorption of $s s$ DNA probe $v s \Delta E$ for a $5 \mathrm{~min}$. time (A) and $v s$ time for $\Delta E=+$ $0.4 \mathrm{~V}$ (B). Electrolyte: $3.0 \mathrm{mM} \mathrm{Fe}(\mathrm{II}) ; 3.0 \mathrm{mM} \mathrm{Fe}(\mathrm{III}) ; 0.5 \mathrm{NaCl}$ and $1.5 \times 10^{-6} \mathrm{M} s s$-DNA probe.

The ratio $I_{\mathrm{ss}} / \mathrm{I}_{\mathrm{Au}}$ decreases slightly when the potential difference $\Delta E$ increases (Figure 2A). $\Delta E=+0.4 \mathrm{~V}$ was chosen for DNA adsorption in order to avoid DNA guanine and $\mathrm{Au}$ oxidations that may occur at higher potential. The evolution of $\mathrm{I}_{\mathrm{SAM}} / \mathrm{I}_{\mathrm{Au}}$ ratio $v s$ adsorption 
time was measured for $+0.05 \mathrm{~V}$ applied potential difference $\Delta E$ (Figure 2B). Five minutes adsorption time was chosen, as $I_{s s} / I_{A u}$, close to $50 \%$, does not decrease beyond this value. The electrochemical adsorption conditions $(\Delta E=+0.4 \mathrm{~V}, t=4 \mathrm{~min}$.) obtained for Pt UME were used to study the performance of a $33 \mu \mathrm{m}$ diameter graphite UME: A value of $64 \% \pm 4 \%$ was obtained for $I_{s S} / I_{A u}$, which is in the range of the one obtained for Pt UME.

Long-range electron transfer across electrochemical adsorbed layers of ss- and ds- DNA. ss-DNA monolayer was adsorbed onto Pt UME surface using optimized conditions and the current was recorded before and after addition of a complementary DNA target in presence of MB as redox intercalator. The current variation mean value measured $(N=13)$ was extremely low and equals to $-0.09 \pm 0.22 \mathrm{nA}$, indicating that hybridization transduction does not occur after saturation of the surface with ssDNA. This result indicates that an electrochemical biosensor consisting of DNA-probe adsorption onto an electrode surface cannot be designed using this transduction pathway. The other way to perform hybridization transduction is then to hybridize the DNA-target in bulk solution and then perform electrochemical adsorption (Scheme 3).

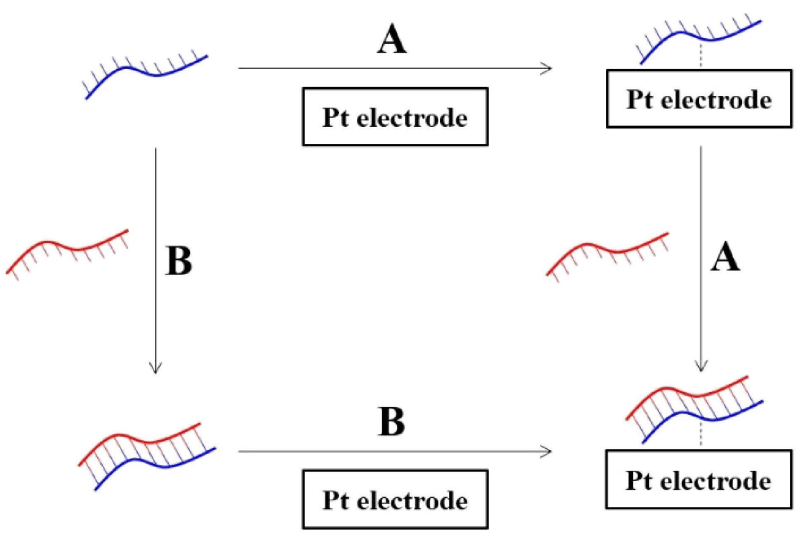

Scheme 3. Two-step transduction pathways: immobilization hybridization (A) and hybridization - immobilization (B).

Thus, long-range electron transfer efficiency was quantified using the $\mathrm{Fe}$ (II) oxidation current ratio $\left(I_{d s}-I_{s s}\right) /$ $I_{s s}$ between single strand ss- and double strand ds- DNA adsorbed layers with or without MB. The ds-DNA solution was prepared by mixing two $1.5 \times 10^{-6} \mathrm{M}$ solutions of complementary ss-DNA (probe and target) during $10 \mathrm{~min}$. The $\mathrm{MB}$ concentration was chosen equal to $10^{-8} \mathrm{M}$, which is well-adapted for catalyzing long-range electron transfer across $d s$-DNA monolayer for UMEs [15]. Current ratio $\left(I_{d s}-I_{s s}\right) / I_{s s}$ was measured 3 to 6 times for each experimental condition (Figure 3).

The obtained results show that the current ratio is close to 0 for DNA adsorbed onto graphite, with or without $\mathrm{MB}$, meaning that there is no significant difference between electron transfer through ss- and ds- DNA

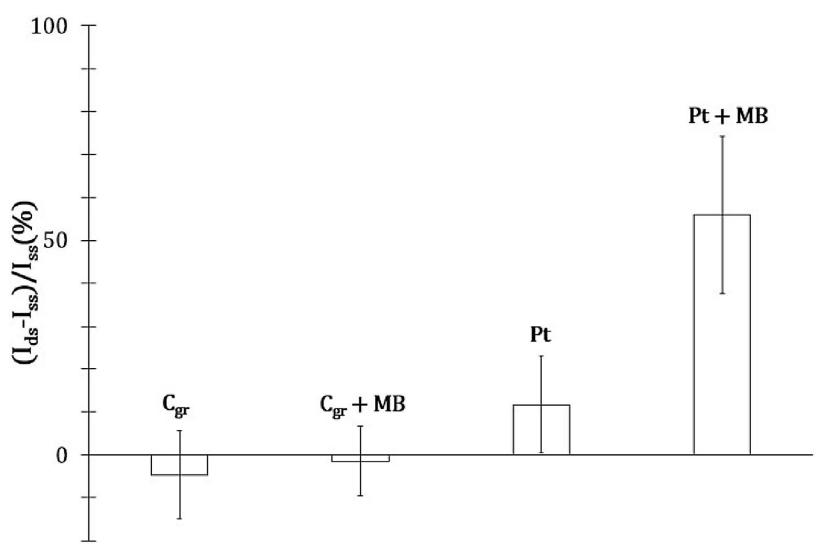

Fig. 3. Long-range electron transfer efficiency $\left(I_{d s}-I_{s s}\right) / I_{s s}$ across electrochemical adsorbed DNA for $33 \mu \mathrm{m}$ diameter graphite $\left(\mathrm{C}_{\mathrm{gr}}\right)$ and $25 \mu \mathrm{m}$ diameter platinum (Pt) UMEs, with and without $10^{-8} \mathrm{M}$ MB. Electrolyte: $0.5 \mathrm{M} \mathrm{NaCl} ; 3.0 \mathrm{mM}$ Fe(III); $3.0 \mathrm{mM} \mathrm{Fe}$ (II) and $10^{-6} \mathrm{M}$ ss- or ds- DNA.

for this electrode material. The current ratio is equal to $12 \%$ without $\mathrm{MB}$ and to $56 \%$ with $\mathrm{MB}$ for adsorbed DNA onto Pt. These results indicate that long-range electron transfer across ds-DNA adsorbed is catalyzed by MB only onto Pt. In the case of graphite, overlaps between $\pi$-conjugated systems of DNA bases and graphene layers of graphite [22] may induce a conformational change of the duplex that prevents long-range electron transfer (Scheme 4).
A

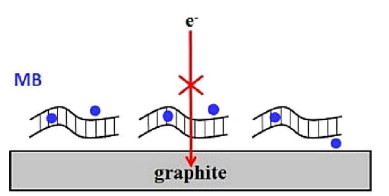

B

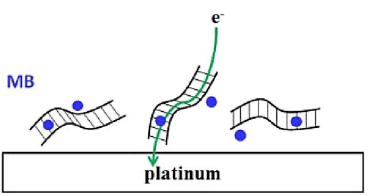

Scheme 4. Proposed long-range electron transfer mechanism across electrochemical adsorbed $d s$-DNA with MB onto graphite (A) and Pt (B) UMEs.

Long-range electron transfer across plasmid layers. Monolayers of 2023 and $4271 \mathrm{bp}$ plasmids (i.e. circular $d s$ DNA) were adsorbed onto platinum UME surface using optimized conditions (i.e. $4 \mathrm{~min}$. at $+0.4 \mathrm{~V}$ ). As the single-stranded forms of these plasmids are not available, electron transfer efficiency was estimated using the ratio $\left(I_{M B}-I\right) / I$ of the current $I_{M B}$ with and $I$ without MB: $I$ is the $\mathrm{Fe}(\mathrm{II})$ oxidation current through the adsorbed plasmid layer measured without $\mathrm{MB}$ and $I_{M B}$ the one measured with MB. The electron transfer efficiency ratios were measured three times for each DNA duplex and compared to a linear 21-base DNA duplex (Figure 4).

The $19 \%$ current ratio value for the $21 b p$-DNA duplex reflects the catalyzed long-range electron transfer properties established above. The current ratios values 


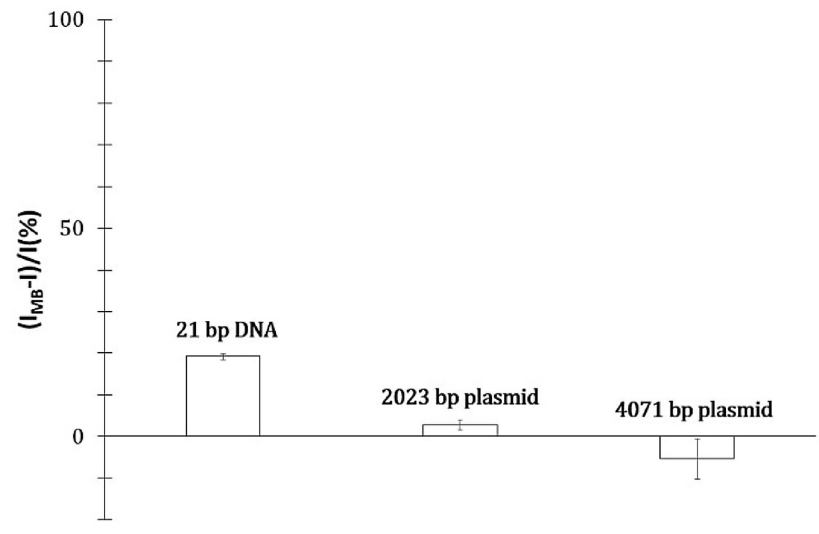

Fig. 4. Long-range electron transfer efficiency $\left(I_{M B^{-}} I\right) / I$ for double-stranded $21 \mathrm{bp}$ synthetic DNA, $2023 \mathrm{bp}$ and $4271 \mathrm{bp}$ DNA plasmids at $10 \mu \mathrm{g} / \mathrm{mL}$ concentration.

were close to 0 for both $2023 b p$ and $4271 b p$ plasmids allow stating that no long-range electron transfer across $d s$-DNA layer occurs. This is consistent for a plasmid that has a circular form where long-range electron transfer cannot occur via the backbone phosphate [11] (Scheme 5).
A

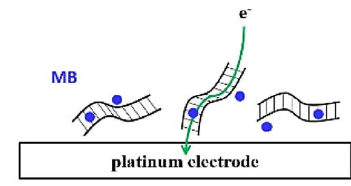

B

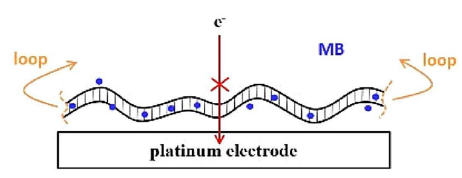

Scheme 5. Long-range electron transfer electrocatalyzed by MB trough linear $d s$-DNA (A) and circular $d s$-DNA (B).

Mismatch detection of synthetic oligonucleotides. The two-step hybridization transduction pathway was used to evaluate mismatch detection of synthetic oligonucleotides by electrochemical adsorption of a duplex. The melting temperature of the 21-base $d s$-DNA used is close to $49^{\circ} \mathrm{C}$ [23], meaning that both perfect matched and mismatched ds-DNA will be stable at room temperature. Mismatch detection was then estimated with the ratio $\left(I_{C}-I_{M}\right) / I_{C}$ between perfect matched and mismatched $d s$-DNA using MB: $\mathrm{I}_{\mathrm{C}}$ is the current measured across the adsorbed layer of the duplex and the complementary target and $\mathrm{I}_{\mathrm{M}}$ the current measured across the adsorbed layer of the duplex with a mismatched target. The current ratios were measured three times for targets with mismatch at different sequence positions (Figure 5).

The current ratios for all the mismatched targets, close to $10 \%$, is high enough to perform single mismatch detection (Scheme 6).

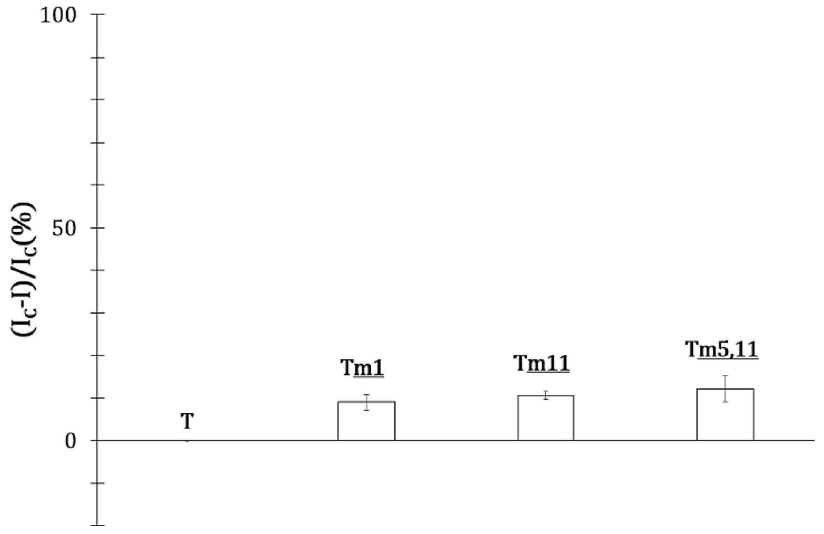

Fig. 5. Mismatch detection current ratio for complementary target $(\mathrm{T})$, mismatched targets in position $1\left(\mathrm{Tm}_{1}\right), 11\left(\mathrm{~T}_{11}\right)$ and 5 and $11\left(\mathrm{~T}_{5,11}\right)$.
A

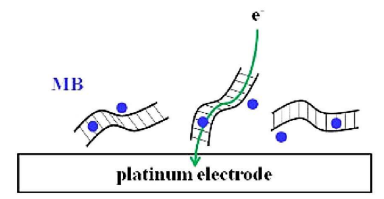

B

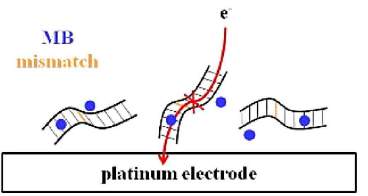

Scheme 6. Long-range electron transfer electrocatalyzed by MB trough perfect matched $d s$-DNA (A) and single mismatched $d s$ DNA (B).

\section{Conclusion}

This study describes a new transduction pathway of DNA hybridization that results from the coupling of two wellknown electrochemical properties: electrochemical adsorption of DNA and long-range electron transfer through double-stranded DNA. It was demonstrated that long-range electron transfer across double-stranded DNA adsorbed without probe labelling (physical adsorption) onto an electrode surface is possible. This transduction pathway presents an interest in synthetic oligonucleotide assay (primers, probes), as it allows single mismatch detection of a duplex, without heating or probe labelling, in a $10 \mathrm{~min}$. protocol using a small DNA sample volume. Single mismatch detection using other analytical methods is not possible in these conditions (i.e. room temperature and no probe labelling).

\section{Associated Contents}

Raw data of the study: electrochemical $I$ vs $\Delta E$ response of $25 \mu \mathrm{m}$ diameter platinum and $33 \mu \mathrm{m}$ diameter graphite ultramicroelectrodes (UMEs).

\section{Acknowledgements}

This work was supported by a grant from the RamanSharpak Fellowship Program exchange between Indian and France for Dr. Nivedita Basu. We wish to thank the 
Maison de l'Inde of Cité Internationale Universitaire de Paris for Dr. Nivedita Basu's room accommodation. Graphite UMEs were fabricated using carbon graphite fibers offered by Dr. Philippe Meunier from the Mersen company (France).

\section{References}

[1] Wang, J.; Cai, X.; Wang, J.; Jonsson, C.; PaleČek, E., Anal. Chem. 1995, 67, 4065-4070.

[2] Wang, J.; Cai, X.; Jonsson, J.; Balakrishnan, M. Electroanalysis 1996, 8, 20-24.

[3] Cai, X.; Rivas, G.; Farias, P. A. M.; Shiraishi, H.; Wang, J.; Fojta, M.; Paleček, E. Bioelectrochem. Bioenerg. 1996, 40, 41-47.

[4] Cai X., Rivas, G.; Shirash, H.; Farias, P.; Wang, J.; Tomschik, M.; Jelen, F.; Paleček, E. Anal. Chim. Acta 1997, 344, 65-76.

[5] Wang, J.; Cai, X.; Tian, B.; Shiraishi, H. Analyst 1996, 121, 965-970.

[6] Wang, J.; Cai, X.; Rivas, G.; Shiraishi, H.; Dontha N. Biosens. Bioelectron. 1997, 12, 587-599.

[7] Wang, J.; Rivas, G.; Cai, X.; Chicharro, M.; Parrado, C.; Dontha, N.; Begleiter, A.; Mowat, M.; Paleček, E.; Nielsen, P. E. Anal. Chim. Acta 1997, 344, 111-118.

[8] Arora, K.; Prabhakar, N.; Chand, S.; Malhotra, B. D. Sens. Actuators B 2007, 126, 655-663.

[9] Alipour, E.; Pournaghi-Azara, M. H.; Parvizi, M.; Golabi, S. M.; Hejazi, M. S. Electrochim. Acta 2011, 56, 1925-1931.

[10] Kelley, S. O.; Holmlin, R. E.; Stemp, E. D. A.; Barton, J. K. J. Am. Chem. Soc. 1997, 119, 9861-9870.
[11] Kelley, S.; Boon, E. M.; Barton, J. K.; Jackson, N. M.; Hill, M. G. Nucleic Acids Res. 1999, 27, 4830-4837.

[12] Nagyand, L.; Ferapontova E. E., Angew.Chem.Int.Ed. 2019, 58, 3048-3052.

[13] Lazerges, M.; Tal, V. T.; Bigey, P.; Scherman, D.; Bedioui, F. Sens. Actuators, B 2013, 182, 510-513.

[14] Zhang, X.; Gao, F.; Cai, X.; Zheng, M.; Gao, F.; Jiang, S.; Wang, Q. Mater. Sci. Eng. 2013, 33, 3851-3857.

[15] Nassi, A.; Guillon, F.-X.; Amar, A.; Hainque, B.; Amriche, S.; Maugé, D.; Markova, E.; Tsé, C.; Bigey, P.; Lazerges, M.; Bedioui, F., Electrochim. Acta 2016, 209, 269-277.

[16] Horny, M. C.; Lazerges, M.; Siaugue, J. M.; Pallandre, A.; Rose, D.; Bedioui, F.; Deslouis, C.; Haghiri-Gosnet, A. M.; Gamby, J. Lab on a Chip 2016, 16, 4373-4381.

[17] Karaayvaz, M.; Pal, T.; Song, B.; Zhang, C.; Georgakopoulos, P.; Mehmood, S.; Burke, S.; Shroyer, K.; Ju, J. Clin Colorectal Cancer 2011, 10, 340-347.

[18] Bloquel, C.; Bejjani, R. A.; Bigey, P.; Bedioui, F.; Doat, M.; Benezra, D.; Scherman, D.; Behar-Cohen F. FASEB J. 2006, 20, 389-391.

[19] Bloquel, C.; Bessis, N.; Boissier, M. C.; Scherman, D.; Bigey, P. Gen. Ther. 2004, 15, 189-201.

[20] IUPAC Gold Book, Faraday constant, 1996, PAC 68, 957.

[21] A. J. Bard, L. R. Faulkner, Electrochemical methods: fundamentals and applications 2nd ed. [2001],Wiley, New York.

[22] Oliveira Brett, A. M.; Chiorcea, A.-M. Electrochemistry Communications 2003, 5, 178-183.

[23] http://biotools.nubic.northwestern.edu/OligoCalc.html [August 29th 2018].

Received: June 1, 2019

Accepted: June 19, 2019

Published online on 


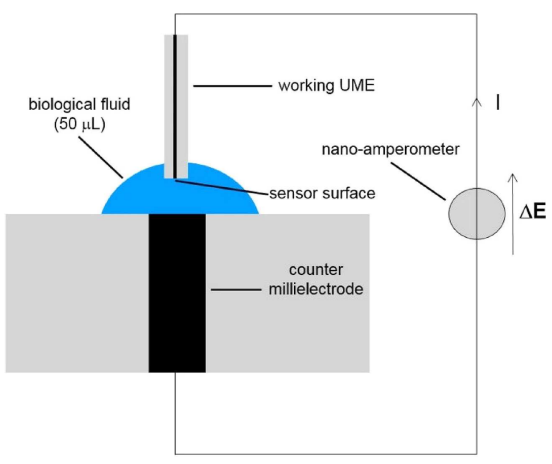

N. Basu, T. H. Ho, F.-X. Guillon, Y. Zhang, P. Bigey, B. Navakanta, $F$.

Bedioui*, M. Lazerges

$1-7$

Coupling Electrochemical Adsorption and Long-range Electron

Transfer: Label-free DNA Mismatch Detection with Ultramicroelectrode (UME) 